\title{
Traumatisk stress og suicidal atferd
}

\author{
Ved Lars Mehlum
}

\begin{abstract}
Både klinisk erfaring og forskning gir klare holdepunkter for at det å ha vært utsatt for traumatisk stress gir en $\emptyset$ kt og langvarig risiko for suicidal atferd. Denne artikkelen fokuserer på samspillet mellom individuelle sårbarhetsfaktorer og traumatiske belastninger i utviklingen av selvmordsrisiko og på mulige mekanismer som kan forklare sammenhengen.
\end{abstract}

\section{ABSTRACT}

Eksponering for ulike former for traumatisk stress forekommer langt hyppigere enn vi vanligvis tenker oss, men blir ofte oversett hos personer som mottar behandling i tilknytning til suicidal atferd. Både klinisk erfaring og forskning gir klare holdepunkter for at eksponering for traumatisk stress gir en $\varnothing \mathrm{kt}$ og langvarig risiko for suicidal atferd. I denne artikkelen gis en oversikt over disse sammenhengene og hvilke faktorer som kan bidra til å forklare dem. Ulike implikasjoner drøftes, og det konkluderes med at i kliniske sammenhenger bør muligheten for traumeeksponering tas i betraktning når selvmordsrisiko vurderes og behandling planlegges. I suicidologisk forskning kan et $\varnothing \mathrm{kt}$ fokus på psykiske traumer gi oss st $\varnothing$ rre kunnskaper om samspillet mellom individuelle sårbarhetsfaktorer og miljøbelastninger i utviklingen av selvmordsrisiko.

Traumatic stress exposure is far more frequent than we usually think, but is often overlooked in patients presenting with suicidal behaviour. Both clinical experience and growing research evidence indicate, however, that exposure to traumatic stress increases the risk of subsequent suicidal behaviour. This paper provides a review of the association between traumatic stress exposure and suicidal behaviour and discusses what factors may contribute to explain this association. Several implications for clinical practice are highlighted.

There is a need to take the possibility of traumatic exposure into consideration in clinical settings when assessing suicide risk and planning interventions and treatments. Furthermore, research into traumatic stress may enhance our understanding of the interplay between individual vulnerability factors and environmental stress in the development of suicidality.

\section{Bakgrunn}

Eksponering for ulike former for traumatisk stress forekommer dessverre langt hyppigere enn vi vanligvis tenker oss. Men slik eksponering blir ofte oversett hos personer som søker hjelp i helsevesenet når det ikke er dette som er det primære utgangspunktet for kontakten eller når traumet ligger i pasientens fortid (Brady et al., 2000). Slik ser det også ut til å være når det gjelder pasienter som mottar behandling $i$ tilknytning til suicidal atferd (Zimmerman og Mattia, 1999). Belastende livshendelser er nok godt kjent som en viktig risikofaktor for suicidalitet, men både forskning og klinisk virksomhet har vanligvis fokusert mest på tapsopplevelser, mellommenneskelige konflikter og andre hendelser som i stor grad tilhører det de fleste må regne med å oppleve. Mindre oppmerksomhet har vært viet til sammenhengen mellom suicidal atferd og traumatiske livshendelser. Plutselige, voldsomme eller dramatiske hendelser som ligger utenfor hva man kan forvente og som gjerne medfører fare for eller tap av liv og helse har et potensiale til å forårsake psykiske traumer. Både klinisk erfaring og forskning gir klare holdepunkter for at det å ha vært utsatt for traumatisk stress gir en $\varnothing \mathrm{kt}$ og langvarig risiko for suicidal atferd. Muligheten for at pasienten har vært eksponert for traumer bør derfor tas i betraktning ved klinisk vurdering av selvmordsrisiko og i behandlingsplanlegging, siden det vil få konsekvenser for behandling. Traumatiske stress-syndromer med tilknyttede problemer kan ha stor innvirkning på det kliniske forløpet. I suicidologisk forskning kan et $\varnothing \mathrm{kt}$ fokus på psykiske traumer gi oss større kunnskaper om samspillet mellom individuelle sårbarhetsfaktorer og miljøbelastninger i utviklingen av selvmordsrisiko. Psykotraumatologien forholder seg til de dyptgripende virkningene som traumatisk stress kan ha på individets oppfatning av seg selv og andre og på evnen til å utvikle og ta vare på stabile og nærende mellommenneskelige relasjoner. Dette er ikke minst viktig når det gjelder utfordringene vi i dag har med fullt ut å forstå og forebygge selvskading blant unge (Hawton et al., 2002, Santa Mina og Gallop, 1998). Denne artikkelen gir en oversikt over hvilke kunnskaper vi i dag har om sammenhengen mellom traumatisk stress og suicidal atferd og om hvilke mekanismer som kan mediere en slik sammenheng. Artikkelen bygger på usystematiske litteraturs $\varnothing \mathrm{k}$ samt forfatterens lange erfaring fra klinikk og forskning om dette temaet.

\section{Hva er traumatisk stress?}

Forskning har vist at både akutte og kroniske belastninger kan gi $\varnothing \mathrm{kt}$ risiko for suicidal atferd og at gjentatt eksponering kan gi en akkumulert risiko

(Heikkinen et al., 1994). Visse typer av belastninger ser imidlertid ut til å ha en ekstra sterk psykologisk virkning. Det gjelder særlig belastninger som gir opphav til sterk frykt eller dødsangst. Det er da gjerne tale om traumatisk stress, og slik belastning kan føre til utvikling av sterke akutte og/eller kroniske psykiske reaksjoner eller symptomdannelse. Hvorvidt den eksponerte personen utvikler slike plager avhenger blant annet av eksponeringens type og intensitet, $\mathrm{i}$ hvilken grad personen reagerte med sterk frykt og hjelpeløshet, individuelle mestringsressurser og st $\varnothing$ tte fra andre under hendelsen og i etterkant.

\section{Hvor vanlig er traumatisk stress?}

I flere studier, blant annet i den såkalte National comorbidity survey (Kessler et al., 1995), er det vist at en overraskende høy andel av den generelle befolkningen - 50-70 \% - har vært eksponert for traumer som er sterke nok til at de ville tilfredsstilt stressorkriteriet i det amerikanske diagnosesystemet DSM-IV (American 
Psychiatric Association, 1994) for posttraumatisk stressforstyrrelse eller PTSD (posttraumatic stress disorder). Dette representerer hendelser som er så alvorlige at de sannsynligvis ville ha forårsaket sterke reaksjoner hos de fleste, selv om bare mellom $15 \%$ og $25 \%$ av de eksponerte vil utvikle PTSD (Breslau et al., 1991, Kessler et al., 1995). De vanligste typene av hendelser er plutselige og uventede dødsfall hos nærstående, ulykker, vold, voldtekt, fysiske og/eller seksuelle overgrep, eller det å være vitne til sjokkerende hendelser eller at andre mennesker blir drept eller alvorlig skadet (Breslau et al., 1998).

Det er viktig å være klar over at de tallene vi har referert til her er framskaffet i epidemiologiske studier fra høyinntektsland i fredstid. I lavinntektsland og for eksempel under krig eller katastrofetilstander kan langt større andel av befolkningen bli eksponert for traumer. Men selv i høyinntektsland i fredstid kan altså mange mennesker bli berørt av traumer utløst av voldsbruk i stor skala. Et dramatisk eksempel på dette var terrorangrepene på New York den 11. september 2001. Man har anslått at mer enn
100000 personer var direkte $\varnothing$ yenvitner til denne katastrofen (Schuster et al., 2001). Et langt st $\varnothing$ rre antall mennesker ble i timene og dagene som fulgte berørt av en sterk opplevelse av faren for nye angrep eller endog for utsiktene til krig. Studier har vist at befolkningen i New York by hadde en betydelig høyere forekomst av PTSD enn i andre amerikanske storbyområder i de første 1-2 år etter angrepet (Schlenger et al., 2002, Yehuda, 2002). Barn var særlig sterkt berørt.

Blant barn i New York rapporterte $18 \%$ alvorlige posttraumatiske stress-symptomer og ytterligere $66 \%$ hadde moderate symptomnivåer i tiden etter angrepet (Fairbrother et al., 2003). Det er viktig å være klar over at ikke bare de som blir fysisk skadet i ulykker, katastrofer, krig og terror vil ha $\varnothing \mathrm{kt}$ risiko for å utvikle posttraumatiske stressreaksjoner. Det gjelder også de som overlever, blir reddet eller evakuert. Og det gjelder innsatspersonell, ledere, helsearbeidere og tilskuere, for ikke å snakke om pårørende, venner og kolleger til dem som er direkte berørt.

Heller ikke Norge har blitt spart for ulykker, katastrofer og terror, noe blant

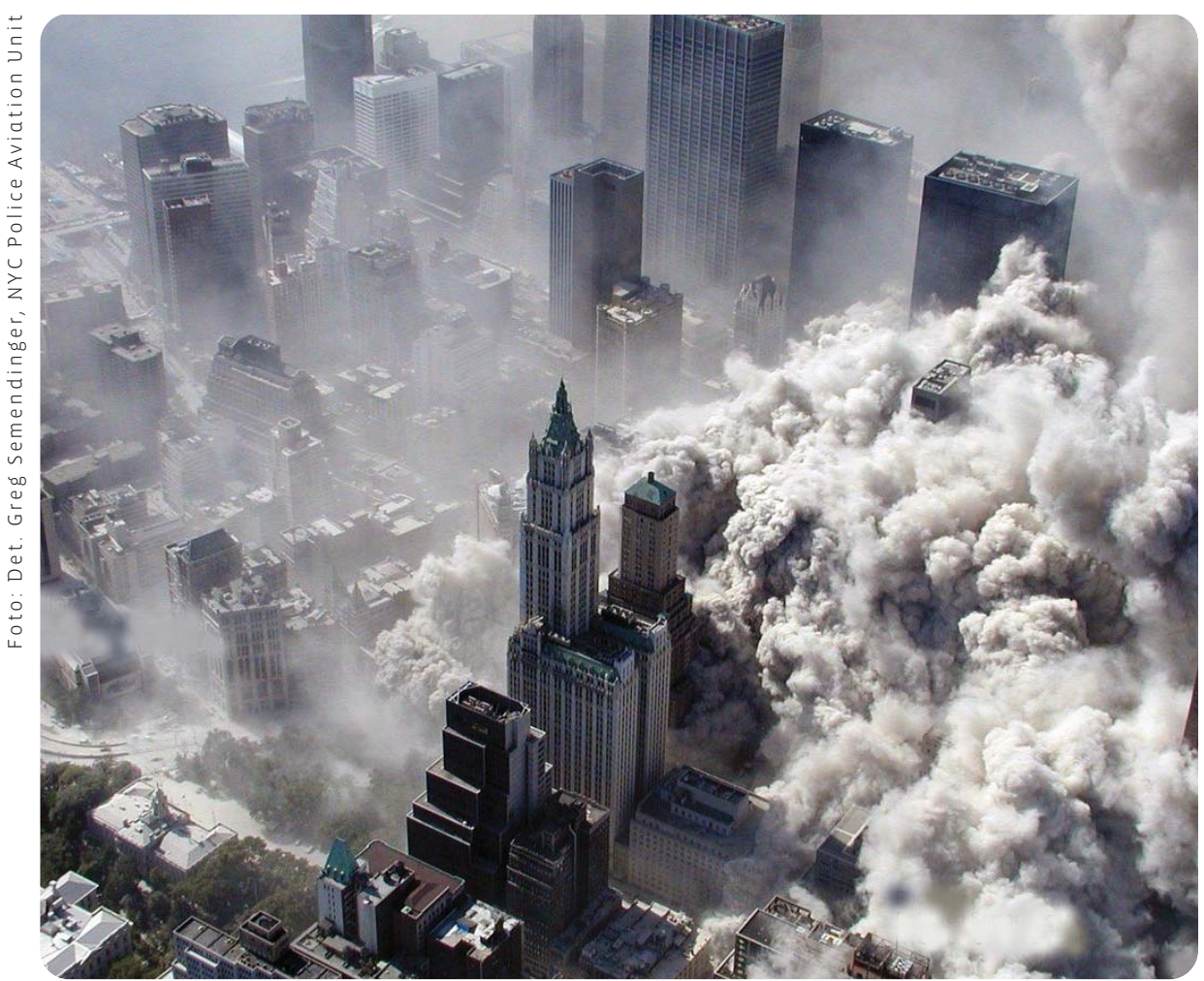

annet angrepene mot regjeringskvartalet og mot AUFs sommerleir på Utøya i 2011 har vist. I følge en foreløpig rapport fra Nasjonalt Kunnskapssenter om vold og traumatisk stress (2012) rapporterte nesten halvparten av dem som hadde vært på Utøya symptomer tilsvarende, eller på grensen til, PTSD ved oppfølging 4-5 månedene etter angrepet. Nesten halvparten rapporterte at de synes det var veldig vanskelig å utføre hverdagslige gjøremål og blant de mange ungdommene som var på $\varnothing$ ya rapporterte ca. $70 \%$ at skoleprestasjonene hadde endret seg til det verre (Glad et al., 2012).

Slike hendelser som vi her har referert til er ekstreme blant annet på grunn av sitt omfang og sine ringvirkninger $i$ samfunnet. Men like ekstrem kan belastningen være for enkeltmennesker som rammes av vold og andre traumer, selv om dette ikke fanger medienes oppmerksomhet eller utløser ekstraordinære hjelpetiltak.

\section{Typer av traumatisk stress}

Posttraumatiske stressreaksjoner kan utløses av kortvarige eller enkeltstående, men overveldende hendelser, slik som ulykker, katastrofer, vold eller liknende. Når traumet har vært forholdsvis avgrenset og av kort varighet - gjerne kategorisert som type I traumatisk stress - ser vi vanligvis manifeste og vedvarende reaksjoner og symptomer på PTSD bare hos dem som har vært eksponert for særlig intense belastninger eller som har en фkt sårbarhet. Ofte oppstår tilleggsproblemer slik som depresjonssymptomer, rusmisbruk, problemer i nære relasjoner (Adams og Lehnert, 1997, Davidson et al., 1991) noe som $\varnothing$ ker risikoen for suicidal atferd. Psykiske traumer som strekker seg ut i tid, som for eksempel langvarige seksuelle og/eller fysiske overgrep mot barn, partnermishandling, krigstraumer eller tortur, kaller vi gjerne type II traumatisk stress (Herman, 1992). Under slike belastninger må den eksponerte personen finne en måte å tilpasse seg til å leve under forhold der videre traumatisering er sannsynlig, og der det er små muligheter for beskyttelse, st $\varnothing$ tte eller for tilheling (Adams og Lehnert, 1997). 
Denne typen vedvarende, sterke belastninger ser ut til å gi opphav til mer sammensatte og dyptgående følgetilstander slik som dissosiative symptomer, atferdsendringer og personlighetsendringer (Herman, 1992, Allen, 2001). I følge noen studier ser type II traumatisering ut til å disponere for et vidt spektrum av selvdestruktiv atferd fra selvskading til selvmord (Molnar et al., 2001, Ystgaard et al., 2004).

\section{Posttraumatisk stressforstyrrelse}

Diagnosen Posttraumatisk stressforstyrrelse (PTSD) bygger if $\varnothing$ lge DSM-IV (American Psychiatric Association, 1994) i første rekke på at personen har vært utsatt for en særlig belastende hendelse som har utløst intens frykt eller skrekk og hjelpeløshet. Diagnosen forutsetter også at personen viser symptomer innenfor tre ulike kategorier som alle er forbundet med sterk angst: a) gjenopplevelse av den traumatiske hendelsen, b) unngåelse av stimuli som minner om den traumatiske hendelsen og c) $\varnothing \mathrm{kt}$ fysiologisk respons. Gjenopplevelsessymptomer arter seg som gjentatte, sterkt ubehagelige og uønskete tanker og indre bilder som opptrer både i våken tilstand og i søvne. Unngåelsen kan arte seg som å unngå å tenke på eller snakke om hendelsen eller å unngå personer, steder eller gjenstander som kan framkalle tanker og følelser knyttet til hendelsen. Mange opplever også følelsesmessig nummenhet og at de har mindre interesse for mennesker og aktiviteter som tidligere var viktige. Symptomer på $\varnothing \mathrm{kt}$ fysiologisk respons kan gi seg utslag i søvnvansker, irritabilitet eller konsentrasjonsvansker samt $\varnothing \mathrm{kt}$ vaktsomhet og skvettenhet.

Diagnosen stilles dersom de symptomene vi her har beskrevet medfører funksjonsnedsettelse og har vart i minst en måned. Symptomene starter vanligvis innen tre måneder etter eksponeringen for traumet. Det er viktig å være klar over at flertallet av dem som eksponeres for traumatisk stress ikke utvikler PTSD eller andre stressrelaterte tilstander. Som vi har nevnt overfor er det en rekke forhold som kan $\varnothing$ ke eller redusere risikoen, men en nærmere beskrivelse av disse er utenfor rammen av denne artikkelen. Vi skal i stedet fokusere nærmere på hva vi vet om sammenhengen mellom traumatisk stress og suicidal atferd.

\section{Suicidal atferd i ulike stress- eksponerte grupper}

Våre kunnskaper om sammenhengen mellom eksponering for traumatisk stress og risiko for suicidal atferd er hentet fra mange typer av studier og populasjoner. Særlig når det gjelder studier av barn som har vært utsatt for overgrep og av ulike grupper som har vært utsatt for krigstraumer, er det et godt kunnskapsgrunnlag. Derimot har forholdsvis få studier vært utført i den generelle befolkningen. Goldney og medarbeidere (2000) fant at traumatisk eksponering var sterkt assosiert med selvmordstanker med en populasjonsattribuerbar risiko på $38 \%$. Med populasjonsattribuerbar risiko menes den andelen av risiko for utvikling av en sykdom eller et utfall som er assosiert med eksponering for den aktuelle risikofaktoren (Caughlin et al, 1994). I det følgende skal vi se nærmere på hva vi vet om sammenhengen mellom eksponering for ulike typer av traumer og risiko for suicidalitet.

\section{Traumatiske tap}

Traumatiske tap ved dødsfall eller annen separasjon er velkjent som risikofaktor i den suicidologiske forskningslitteraturen. Det er også en risikofaktor som klinikere i møte med suicidale pasienter ofte legger betydelig vekt på. Tallrike studier har vist at både selvmordsforsøkere og personer som fullfører selvmord har en signifikant $\varnothing \mathrm{kt}$ tendens til å ha vært utsatt for tapstraumer tidlig i livet (Bron et al., 1991, Wasserman og Cullberg, 1989), eller på et senere stadium (Qin og Mortensen, 2003). En slik risiko trenger imidlertid ikke henge sammen med en direkte traumatisk effekt. Studier har vist at konsekvensene for et barn av tap av en forelder i stor grad er en funksjon av hvordan den gjenværende forelderen mestrer den vanskelige situasjonen og hvorvidt barnets daglige milj $\varnothing$ og levekår forandrer seg til det verre som følge av tapet (Adams et al., 1982). Den gjenværende forelderens evne til å hjelpe barnet til å sørge og til å mestre tapet er av avgjørende betydning. Direkte traumatiske effekter ser man imidlertid særlig der personer blir vitner til andres plutselige, uventede og/eller voldsomme $\mathrm{d} \varnothing \mathrm{d}$ og særlig hvis det dreier seg om en nærstående. At slik eksponering er assosiert med senere suicidal atferd er godt dokumentert i studier av personer som har blitt etterlatt ved selvmord (Ness og Pfeffer, 1990, Prigerson et al., 1999).

\section{Fysiske og seksuelle overgrep mot barn}

De klareste indikasjonene for en sammenheng mellom traumatisk eksponering og risiko for suicidal atferd har vi trolig fra studier av overgrepsutsatte barn og unge både i befolkningsstudier (Davidson et al., 1996, Silverman et al., 1996, Bensley et al., 1999, Molnar et al., 2001, Santa Mina og Gallop, 1998) og i ulike kliniske utvalg hentet fra primærhelsetjenesten (Gould et al., 1994), somatiske sykehus (Ystgaard et al., 2004) og psykisk helsevern (Briere et al., 1989, 1997, Brown og Anderson, 1991, Kaplan et al., 1995, Lipschitz et al., 1999). Det er hevet over tvil at fysiske og/eller seksuelle overgrep mot barn i betydelig grad $\varnothing$ ker risikoen for selvskading og selvmordsforsøk både i ungdomsårene og i voksen alder. Men det er fortsatt uklart om seksuelle overgrep mot barn $\varnothing$ ker risikoen for selvmord (White og Widom, 2003). Forekomsten av slike overgrep er høy. I norske studier har man funnet at 10-20\% av jenter og 1-14\% av gutter har vært utsatt for overgrep (Sætre et al, 1986), noe som stemmer rimelig bra med tall fra andre land (Molnar et al., 2001).

I lys av dette er det ikke overraskende at den populasjonsattribuerbare risikoen for seksuelle overgrep mot barn i forhold til selvmordsfors $\varnothing \mathrm{k}$ har blitt estimert til 9-20\% (Brown et al., 1999, Molnar et al., 2001). Denne risikoen ser ut til å være forh фyet gjennom hele livet (Dube et al., 2001), selv om en rekke andre risikofaktorer som psykisk lidelse, rusmisbruk og negative livshendelser som opptrer senere også spiller en stor rolle. 


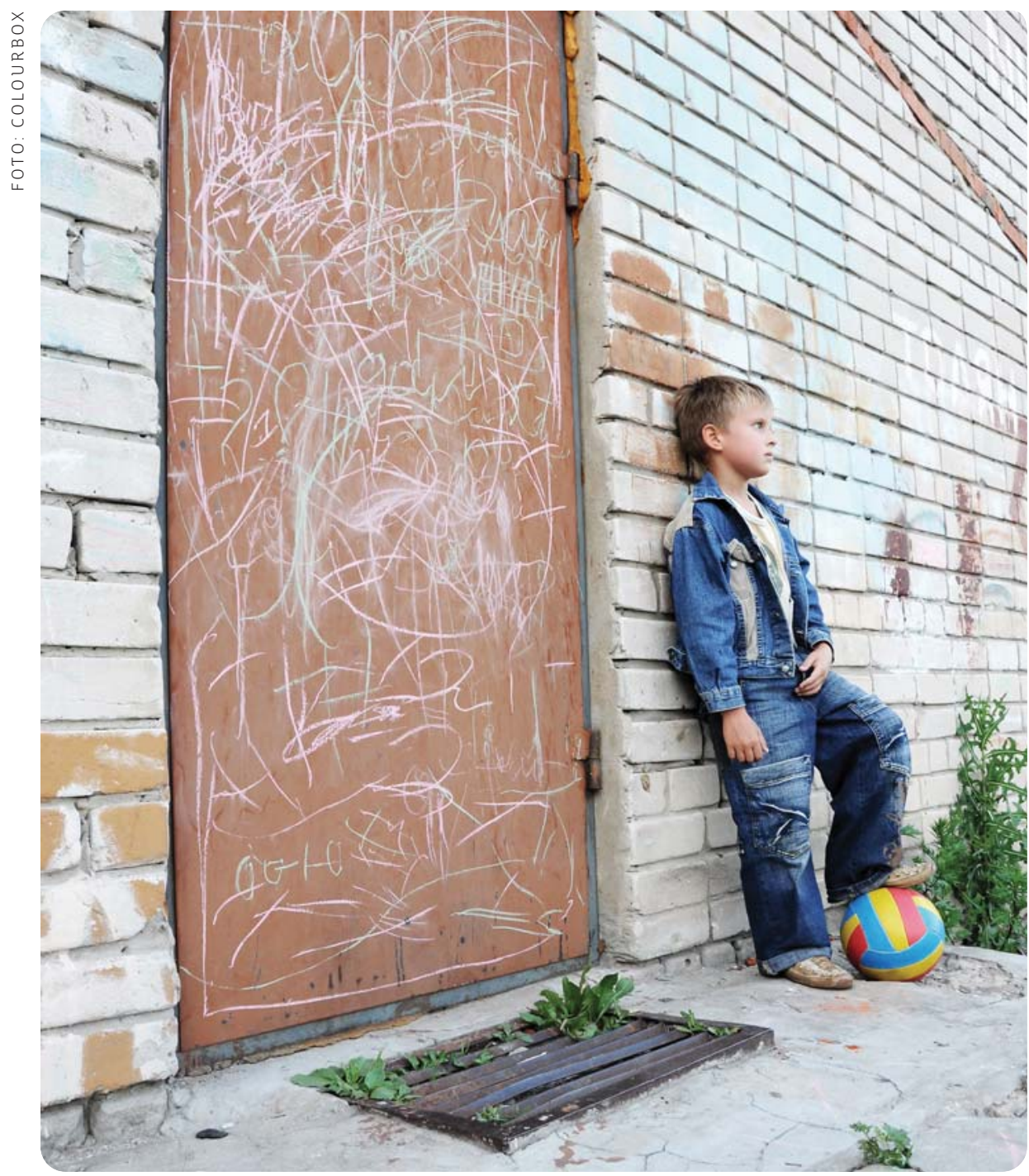

Personer som har vært utsatt for seksuelle overgrep som barn, har også en særlig godt dokumentert risiko for gjentatt suicidal atferd (Brown og Anderson, 1999, Ystgaard et al., 2004). Mange klinikere betrakter derfor gjentatt eller kronisk suicidal og selvskadende atferd hos en ung kvinnelig pasient som en sterk indikator på at vedkommende har vært utsatt for seksuelle overgrep. Epidemiologiske studier gir avgjort st $\varnothing$ tte for en ekstra årvåkenhet i slike tilfeller, samtidig som hver sak må vurderes for seg uten for sterke forhåndsantakelser. En stor andel av unge pasienter med kronisk selvskading og/eller suicidalitet fyller kriteriene til ustabil personlighetsforstyrrelse i tillegg til PTSD (Mehlum, 2012). Studier har vist at personer som har vært utsatt for seksuelle overgrep i barndommen og som har utviklet kronisk selvskading også ofte har store problemer med å regulere impulser, emosjoner og atferd (Stanley et al., 2001), noe som er konsistent nettopp med ustabil personlighetsforstyrrelse.

\section{Vold}

Dessverre ser det ikke ut til å være ende på variasjonsbredden i vold som utøves i menneskelig samhandling, selv om vi bare tar i betraktning vår egen relativt fredelige og velorganiserte del av verden. I private hjem, i gatene, på skoler, arbeidsplasser eller andre institusjoner forekommer daglig en stor mengde av voldshandlinger. Tar vi også med i betraktning andre verdensregioner eller vår egen ikke altfor fjerne fortid, fortoner problemet seg enda mer omfattende. På tross av dette er det fortsatt mangel på systematisk kunnskap om konsekvensene av vold for den enkelte når det gjelder risikoen for suicidal atferd. Studier har likevel vist at det er en klar sammenheng mellom voldtekt og senere selvmordstanker (Dahl, 1989) eller suicidal atferd (Ullman og Brecklin, 2002). Kvinner som har vært utsatt for seksuelle overgrep i barndommen og som senere blir utsatt for voldtekt har en særlig høy risiko for suicidal atferd selv når man kontrollerer for sosiodemografiske og psykososiale karakteristika (Ullman og Brecklin, 2002, Cloitre et al., 1997).

Ferrada-Noli og medarbeidere (1998a) fant en klar sammenheng mellom traumeeksponering, PTSD og suicidal atferd i sin intervjustudie med flyktninger som hadde opplevd fangenskap, tortur og/ eller seksuelle overgrep. Blant dem som hadde vært utsatt for tortur og som senere hadde utført selvmordsfors $\varnothing \mathrm{k}$ var forskerne interessant nok i stand til å påvise en sammenheng mellom torturmetoden og torturofferets senere valg av metode for selvmordsfors $\varnothing$ ket (FerradaNoli et al., 1998b). Vanntortur var eksempelvis assosiert med selvmordsfors $\varnothing \mathrm{k}$ ved drukning, og tortur ved bruk av skarpe gjenstander var assosiert med selvmordsfors $\varnothing \mathrm{k}$ ved knivstikk eller kutting.

\section{Krigstraumer}

I sin klassiske og velkjente studie fant Emil Durkheim at selvmordsratene har en fallende tendens i den generelle mannlige befolkningen under krig (Durkheim, 1897). Dette fenomenet er påvist også i studier fra moderne tid (Grubisic-Ilic et al., 2002) og forklares som en effekt av $\varnothing \mathrm{kt}$ sosialt samhold (eller sosial integrasjon) som finner sted når et samfunn utsettes for en ytre trussel. Når man studerer mulige effekter av krig på forekomsten av selvmord i et samfunn er det derfor viktig å huske at beskyttende mekanismer, slik som $\varnothing \mathrm{kt}$ sosial st $\varnothing t t e$, kan bli aktivert. For dem som har vært direkte utsatt for krigstraumene ser imidlertid effektene på gruppenivå hovedsakelig ut til å være negative. 
Kanskje den sterkeste evidensen for dette er framskaffet gjennom de amerikanske studiene i etterkant av Vietnamkrigen. Den store populasjonen av amerikanske veteraner (mer enn fem millioner) fra denne krigen har en signifikant $\varnothing \mathrm{kt}$ selvmordsrisiko, særlig dem som utviklet PTSD (Bullman og Kang, 1994) eller som ble fysisk skadet (Bullman og Kang, 1996). Blant disse veteranene er det også påvist $\varnothing \mathrm{kt}$ forekomst av selvmordstanker og selvmordsfors $\varnothing \mathrm{k}$, og igjen er dette sterkt assosiert med det å ha fått diagnosen PTSD. Dersom ytterligere psykiatriske diagnoser er blitt påvist, særlig depresjon, er denne assosiasjonen enda sterkere (Kramer et al., 1994, Hendin og Haas, 1991). Flere studier har unders $\varnothing \mathrm{kt}$ hvilke følger moderne krigføring eller fredsbevarende oppdrag kan få for involvert militært personell. Oppgavene og rollene er gjerne mer komplekse enn tidligere, og det kan være vanskelig å opprettholde motivasjon og en opplevelse av meningsfullhet når arbeidet og innsatsen virker nytteløs. Mange får også problemer med å tilpasse seg det vanlige livet ved hjemkomst etter endt tjeneste. Det å ha vært utsatt for kamp, beskytning og andre typer av krigssonestress er en sterk prediktor for utvikling av PTSD hos veteraner fra militære operasjoner både på kort (Litz et al., 1997) og lang sikt (Mehlum og Weisæth, 2002).

At slik tjeneste også kan medføre $\varnothing \mathrm{kt}$ risiko for selvmord er blant annet vist i en norsk studie av Thoresen og medarbeidere (2003) der overd $\varnothing$ deligheten ved selvmord ble funnet å være 40 \% etter en observasjonstid på opptil 17 år etter tjenesten. I løpet av de senere år er oppmerksomheten igjen $\varnothing \mathrm{kt}$ i forhold til sammenhengen mellom krigstraumer og risiko for suicidal atferd, både blant aktivt tjenestegjørende personell og blant veteraner. USA og en rekke andre land i vest har igjen hatt store militære kontingenter engasjert i kriger på ulike kontinenter og selvmordstallene har $\varnothing \mathrm{kt}$. Under krigene i Irak og Afghanistan $\varnothing$ kte selvmordsraten i den amerikanske hær fra 12,4 (/100 000) i 2003 til 18,1 i 2008 (Tanielian et al, 2008).

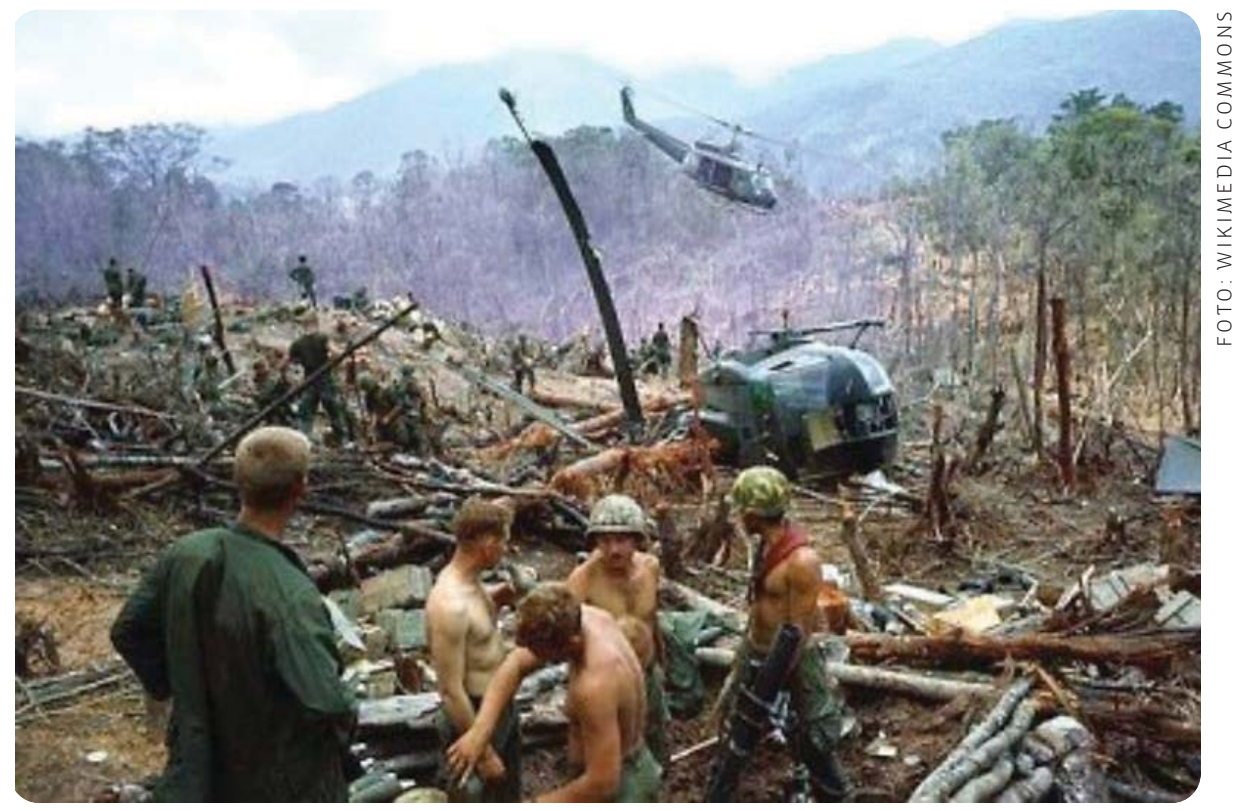

Vietnamkrigen varte fra ca. 1955 til 1975

I Storbritannia er selvmordsraten blant veteraner fra Falklandskrigen tre ganger så høy som blant veteraner fra vanlig britisk militærtjeneste (Kapur et al, 2009).

Til slutt i denne gjennomgangen kan det være naturlig å nevne spesielt et par norske studier som har unders $\varnothing \mathrm{kt}$ sammenhengen mellom ulike typer for traumeeksponering og suicidalitet. Blant 74 selvmordsfors $\varnothing$ kere innlagt i somatisk sykehus fant Ystgaard og medarbeidere høye forekomster av alvorlige seksuelle (35\%) eller fysiske (18\%) overgrep, og eksponering for familievold (31\%)

(Ystgaard et al., 2004). Fysisk og seksuelt misbruk var sterkt assosiert med å ha hatt gjentatte selvmordsfors $\varnothing \mathrm{k}$, selv når man kontrollerte for effekten av andre belastninger i barndommen. I en annen norsk studie av 139 pasienter som ble lagt inn psykiatrisk sykehus fant Floen og Elklit (2007) på samme måte høye forekomster av eksponering for ulike typer av traumatisk stress både i livstidsperspektiv og i løpet av siste år. En rekke former for traumer var assosiert med å ha hatt selvmordstanker siste måned, mens å ha vært utsatt for voldtekt eller å ha vært truet med et våpen var signifikant assosiert med å ha utf $\varnothing$ rt selvmordsfors $\varnothing \mathrm{k}$.

Vi har beskrevet noen eksempler på sammenhenger mellom eksponering for traumatisk stress og $\varnothing \mathrm{kt}$ risiko for suicidal atferd. Mange flere typer av traumer kunne vært nevnt, men i mange tilfeller mangler det forskning på denne sammenhengen. Men selv om det er et sterkt behov for mer kunnskap, er det likevel mulig å konkludere med at det er evidens fra både kliniske og epidemiologiske studier for en sammenheng mellom psykisk traumatisering og et bredt spekter av selvskadende og suicidal atferd. I det følgende skal vi se nærmere på hva denne sammenhengen innebærer.

Traumatisk stress og suicidal atferd - medierende mekanismer

Når vi vil studere mulige mekanismer som kan mediere sammenhengen mellom traumeeksponering og suicidal atferd, st $\varnothing$ ter vi raskt på flere metodiske problemer. Det kan blant annet dreie seg om multiple samtidige eller påfølgende traumer, og det å studere effekten av enkelttraumer kan da bli svært vanskelig. Informasjon vi samler om eksponering for psykiske traumer kan også bli forvrengt med tiden, på grunn av amnesi eller disossiative symptomer eller på grunn av tabuer og sosiale konvensjoner. Disse metodiske problemene er det viktig å ha i mente når vi i det følgende skal diskutere noen mulige veier som leder fra traumeeksponering til suicidal atferd. 


\section{Dose-respons-forhold}

For flere typer av traumeeksponering later det til å foreligge et dose-responsforhold for hvordan en belastning kan $\varnothing$ ke risikoen for suicidal atferd. 'Dosen' kan her eksempelvis være definert ut fra alvorsgraden av traumet, varigheten, antallet av hendelser, om det forelå livsfare og ut fra om traumet var et resultat av menneskelig vilje eller var et uhell. Ganske riktig har flere studier vist et dose-responsforhold for seksuelle overgrep mot barn i forhold til risiko for suicidal atferd (Santa Mina og Gallop, 1998, Molnar et al., 2001). For krigsrelaterte traumer er det klar evidens for et dose-responsforhold når det gjelder risikoen for å utvikle PTSD (Fontana og Rosenheck, 1994), men ikke direkte i forhold til risiko for suicidal atferd. I en amerikansk studie av om lag 10000 personer i normalpopulasjonen fant imidlertid Marshall og medarbeidere (2001) en sterk sammenheng mellom antallet av selvrapporterte PTSD-symptomer og risikoen for samtidig å ha selvmordstanker.

\section{Utvikling av psykisk lidelse}

I nyere befolkningsstudier er det påvist en sammenheng mellom PTSD og risiko for selvmord. I en dansk registerbasert studie fant man en femdoblet risiko for selvmord blant personer med PTSD sammenliknet med personer uten PTSD selv når man kontrollerte for annen psykisk lidelse og sosiodemografiske variabler (Gradus et al, 2010). Noen studier har gitt indikasjon for at PTSD kan mediere forholdet mellom traumeeksponering og suicidal atferd (Mazza et al., 1999). Og enkelte studier kan faktisk tyde på at PTSD spiller en avgjørende rolle for hvorvidt suicidaliteten skal resultere i konkret selvmordsatferd. I studien til Wilcox et al. (2009) var det bare personer som hadde utviklet PTSD etter traumet som hadde en $\varnothing \mathrm{kt}$ risiko for selvmordsfors $\varnothing \mathrm{k}$. Blant personer med PTSD ser det også ut til at dem som i tillegg også har markert depresjon (Oquendo et al., 2003) har en særlig $\phi \mathrm{kt}$ risiko for suicidalitet. Det er vanligvis en høy komorbiditet mellom PTSD og markert depresjon (van der Kolk et al., 1991), og disse psykiske lidelsene har sannsynligvis en kumulativ innvirkning på suicidalitetsrisikoen. En gruppe som har en særlig sterk samvariasjon mellom PTSD og suicidal atferd er personer som har vært utsatt for seksuelle overgrep i barndommen (Widom, 1999). I en studie av personer med PTSD hadde to tredeler av dem som hadde vært utsatt for seksuelt misbruk før 14-årsalder ett eller flere selvmordsfors $\varnothing \mathrm{k}$ i sykehistorien (van der Kolk et al., 1991). Blant dem som hadde vært utsatt for seksuelle overgrep senere i livet og blant dem som hadde vært utsatt for andre typer av traumer, var det en betydelig lavere tendens til suicidal atferd.

Spørsmålet om hvorvidt risikoen for suicidal atferd er helt ut mediert gjennom utvikling av psykisk lidelse har vært diskutert, men er uavklart. De fleste studier av dette spørsmålet har vært utført blant personer som har vært utsatt for seksuelle overgrep i barndommen. I en omfattende longitudinell studie i New Zealand der man fulgte 1265 barn fra fødselen og gjennom 21 år, fant man at ingen av traumene deltakerne hadde vært utsatt for i barndommen predikerte suicidal atferd dersom man justerte for psykisk lidelse og belastende livshendelser som inntraff i tenåringsperioden (Ferguson et al, 2000). Motsatt viste Molnar og medarbeidere i en studie fra USA (2001) at en signifikant andel (20-30 \%) av selvmordsfors $\varnothing$ kene hos traumeeksponerte ikke var relatert til psykiske lidelser. Sannsynligvis vil studier av sammenhengen mellom psykisk lidelse og suicidal atferd hos traumeeksponerte være mest meningsfulle og gi sikrest informasjon dersom de fokuserer på spesifikke forhold ved de ulike syndromer og diagnoser som kan spille en rolle i en kompleks suicidal prosess. Kaplan og medarbeideres kliniske studie av pasienter med og uten PTSD viste eksempelvis at den $\varnothing \mathrm{kte}$ risikoen for suicidal atferd hos pasienter som hadde PTSD i stor grad kunne knyttes til disse pasientenes svakere skårer på mestringsvariabler (1999).

\section{Dissosiative mekanismer}

Dissosiative symptomer forekommer ofte hos individer som har vært utsatt for traumatisk stress, skjønt forholdet mellom traume og dissosiasjonssymptomer er langt fra lineært. Det er vanlig å definere dissosiasjon som et brudd i vanlige integrerte funksjoner av bevissthet, hukommelse, identitet og persepsjon av miljøet (American Psychiatric Association, 1994). Denne definisjonen omfatter fenomener som amnesi, depersonalisering, derealisering, personlighetsforstyrrelser (for eksempel multippel personlighet), og i ekstreme tilfeller, psykotiske symtomer. En måte å forstå dissosiative symptomer på er å se dem som en metode til følelsesmessig å distansere seg fra traumet. I det minste på kort sikt kan dette fungere dette som en psykologisk forsvarsmekanisme mot uutholdelig og uunngåelig fysisk og psykisk smerte. Med gjentatt eller langvarig traumatisk eksponering kan imidlertid dette utvikle seg til et mønster som kan svekke mestringen. Studier har vist at mennesker med gjentatt selvskading pleier å ha $\varnothing \mathrm{kt}$ nivå av dissosiative symptomer (van der Kolk et al., 1991). I følge Orbach (1994), kan denne tendensen til å velge å unnslippe/unngå i stedet for forholde seg til den psykiske smerten bidra til å $\varnothing$ ke følelsen av håpløshet og hjelpeløshet og fremme utvikling av selvdestruktiv atferd. På lang sikt kan dermed dissosiasjon medføre en sårbarhetstilstand som disponerer for selvdestruktiv atferd blant personer som er utsatt for gjentatte traumer i et invaliderende og lite st $\varnothing t t e n d e$ milj $\varnothing$.

\section{Overgenerell autobiografisk} hukommelse

Overgenerell autobiografisk hukommelse er et kognitivt fenomen som kan tenkes å $\varnothing$ ke risikoen for selvmordsatferd, og dette har vært godt beskrevet i flere studier av Williams og medarbeidere. I sin forskning har de vist at suicidale personer har problemer med å huske spesifikke minner om seg selv i fortid (Williams et al., 1996). De har en tendens til å svare på en mer generell eller mindre spesifikk måte enn friske kontrollpersoner når de 
for eksempel blir bedt om å huske en hendelse fra sin fortid som gjorde dem glade. Williams antar at en mulig årsak til dette fenomenet kan være at disse personene gjerne plages av mange og påtrengende minner fra tidligere traumer og at deres overgenerelle hukommelse kan ha en følelsesregulerende funksjon ved å skape st $\varnothing$ rre avstand til minnene (Williams et al., 1996). Mens denne tendensen til å huske på en mindre spesifikk måte kan gi beskyttelse og lindring i фyeblikket, har det vært hevdet at dette på langt sikt kan redusere effektiv bruk av hukommelsen i daglig problemløsning (Raes et al., 2003). Manglende evne til problemløsning er typisk for mange suicidale personer. For mange klinikere kan et slikt syn på dissosiative symptomer trolig passe bra med deres kliniske erfaring, men det gjenstår å teste ut slike antakelser i kliniske studier. Startup og kollegaers (2001) studie av pasienter med ustabil personlighetsforstyrrelse viste interessant nok at de pasientene som hadde st $\varnothing$ rst tendens til overgenerell hukommelse rapporterte færrest selvskadehandlinger. Forskerne antok dermed at overgenerell autobiografisk hukommelse kan fungere som en forsvarsmekanisme for personer med ustabil personlighetsforstyrrelse ved å hjelpe dem til å unngå invaderende og ubehagelige minner og dermed redusere risikoen for selvdestruktiv atferd.

Forskning på traumatisk stress har i dag et sterkt fokus på hjernens hukommelsessystemer. Forhåpentligvis vil noe av denne forskningen føre til utvikling av behandlingstiltak som kan redusere risikoen for suicidal atferd hos traumatiserte individer. Dette eksemplet er fra et avskjedsbrev skrevet av en 17 år gammel gutt som tok sitt eget liv:

"Hvorfor jeg har bestemt meg for å ta mitt eget liv? Fra jeg var fire år gammel til jeg ble ni ble jeg seksuelt misbrukt. Jeg bare klarer det ikke lenger. Det er noe som jeg aldri kan legge bak meg. Minnene og de indre bildene er så levende. Og det er som om min selvfølelse er blitt knust mot en stein."

\section{Andre kognitive mekanismer}

I diskusjonen av kognitive mekanismer som kan ha forklaringsverdi for sammenhengen mellom traumatisk eksponering og risiko for suicidal atferd bør også nevnes velkjente fenomener som ofte er beskrevet i kliniske utvalg av suicidale personer. Kognitive fenomener som blant annet lav selvfølelse, hjelpeløshet, håpløshet, rigid eller dikotom tenkning, selektiv persepsjon og negative attribusjoner om årsaksfaktorer, skyld og ansvar betraktes vanligvis som deler av depressive tilstander. Men i noen sammenhenger
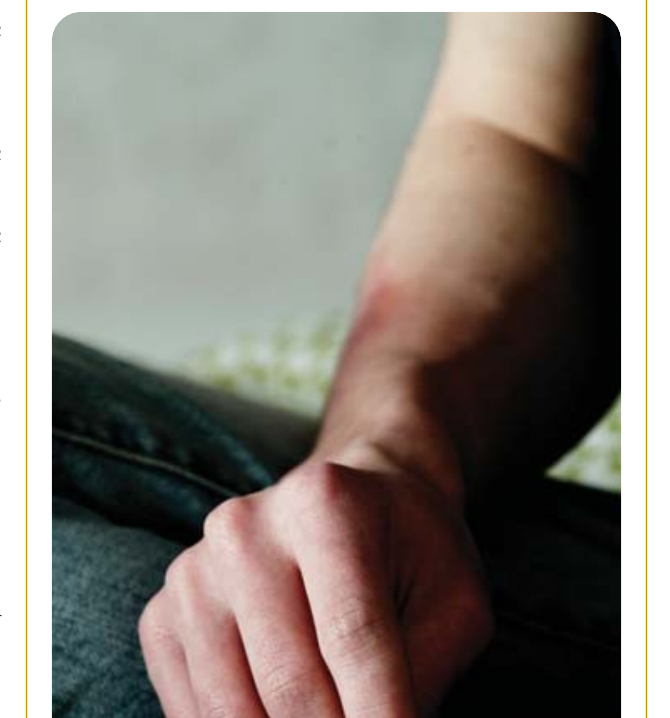

(n)

(

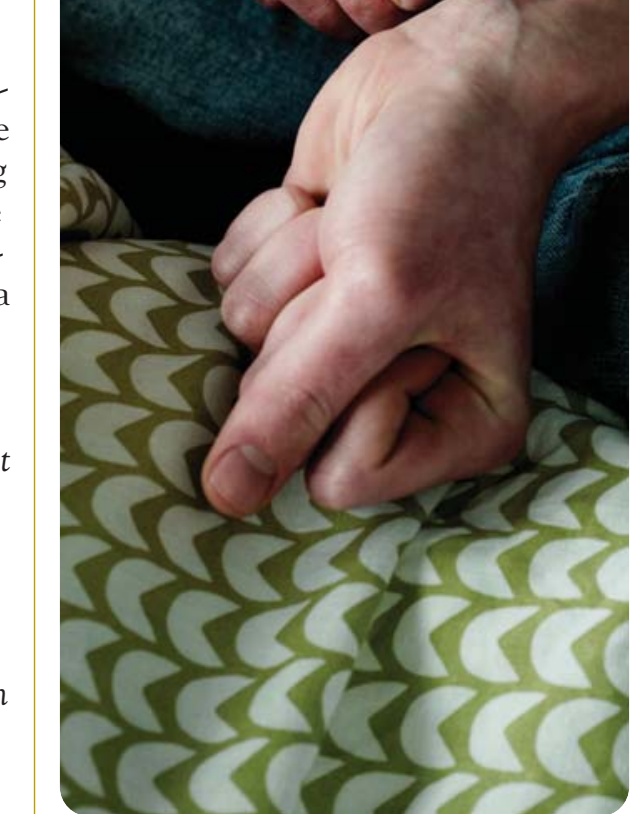




\section{Noen implikasjoner for selv- mordsforebygging og klinisk praksis}

Som vi har sett er det god evidens for at suicidal atferd i både den generelle befolkningen og i kliniske populasjoner kan ha sammenheng med eksponering for traumatisk stress. Imidlertid er medierende mekanismer fortsatt ikke godt forstått, og det er et stort behov for $\varnothing \mathrm{kt}$ forskning på disse kompliserte forholdene. Denne forskningen bør søke å integrere kunnskap fra traumeforskningen og suicidologisk forskning, og dessuten kombinere nevrobiologiske og psykologiske forskningsmetoder. Men også klinikere bør ha et våkent $\varnothing y e$ for sammenhengen mellom traumer og suicidal atferd. Det vil ellers være stor risiko for at mulige traumatiske opphav til problemer ikke blir avdekket når pasienter kommer i kontakt med hjelpeapparatet i forhold til suicidal atferd. Eller, omvendt, at symptomer på selvmordsrisiko blir oversett når den presenterte problemstillingen er traumatisk stress. En årsak til denne dårlig integrerte praksisen kan være at både selvmord og mange slags traumatisk stress (seksuelt misbruk av barn, familievold osv.) fortsatt er sterkt tabubelagte tema. Derfor kan både helsepersonell og pasienter $\varnothing$ nske å unngå dem hvis mulig. En annen opplagt årsak til mangelen på en integrert tilnærming kan være at mange klinikere mangler tilstrekkelig kunnskap om sammenhengen mellom traumatisk stress og suicidal atferd. Kanskje det viktigste vi kan gjøre for å bedre praksis er å øke kunnskapen hos klinikere med ansvar for vurdering og behandling av suicidale pasienter.

En annen måte å sikre at traumatisk stress ikke blir oversett i kliniske evalueringsprosesser er å ta i bruk bedre metoder og rutiner for systematisk vurdering av forskjellige slags traumer og den rollen disse traumene kan spille i utviklingen av selvdestruktiv atferd. Noen slike instrumenter eksisterer, men de blir vanligvis ikke brukt i rutinepraksis. De er heller ikke godt samkjørt med de generelle psykiatriske vurderingsinstrumentene.

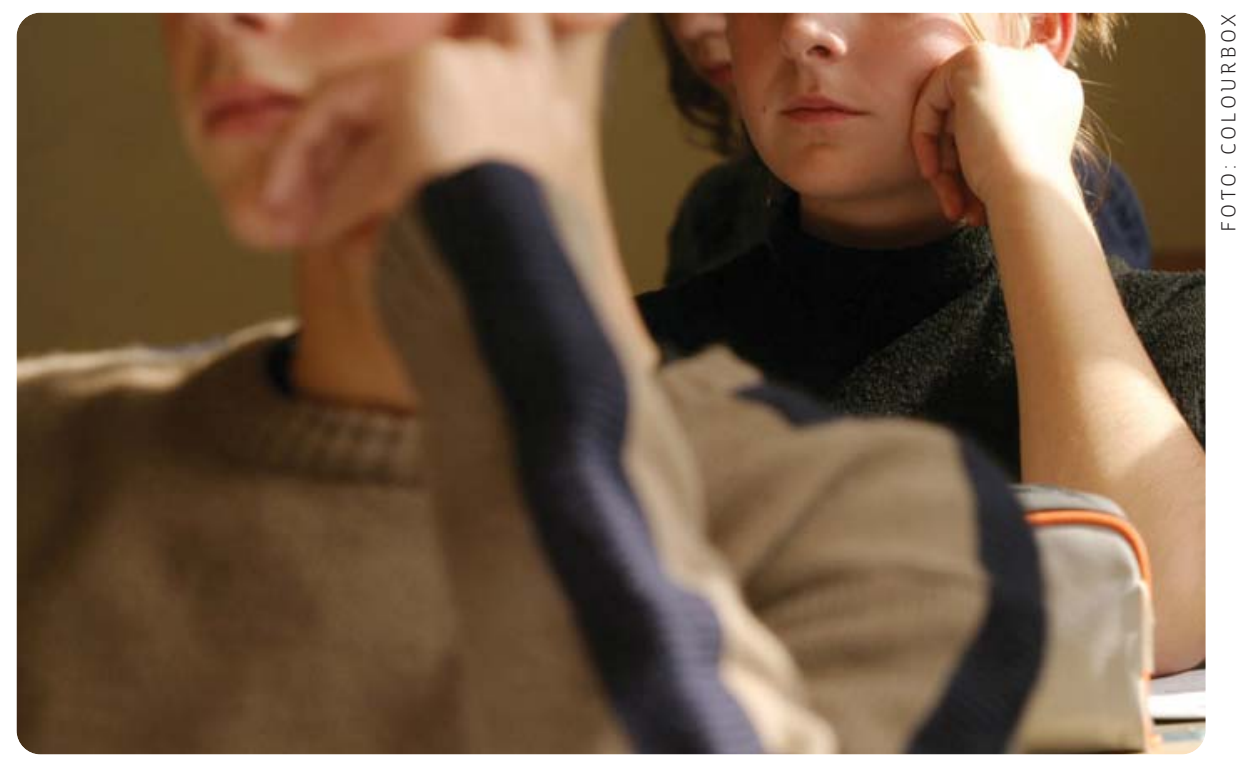

Bare en brøkdel av alle dem som har $\varnothing \mathrm{kt}$ risiko for selvmord vil få en ekspertvurdering av sin suicidalitet og relaterte problemer. Og hvis det stemmer at ikke all suicidal atferd som kommer i kjølvannet av traumatisk stresspåvirkning er mediert gjennom psykisk lidelse, da trenger vi å utvikle unders $\varnothing$ kelser eller screeningprosedyrer som kan anvendes utenfor kliniske settinger. Skolesektoren er en slik arena. Det er behov for at barn som har vært utsatt for seksuelt misbruk og/eller annet misbruk vies st $\varnothing$ rre oppmerksomhet. Siden koblingen mellom seksuelt misbruk i barndommen og senere suicidal atferd er så godt dokumentert, er tidlig oppdagelse og intervensjon for alle traumatiserte barn og ungdommer svært viktig. Skolen er den arena hvor vi kan håpe å få kontakt med noen av de mest risikoutsatte barna - de som har foreldre med alvorlige psykiske lidelser, rusmisbruk eller andre problemer som kan svekke deres evne til å beskytte barna mot misbruk.

Hvordan forebyggings- og behandlingsprogrammer for traumeeksponerte $b \varnothing r$ utformes faller utenfor rammen av denne artikkelen å omtale. Her skal vi begrense oss til å understreke det generelle behovet for å inkludere vurdering av selvmordsrisiko i de kliniske evalueringene som utføres og i planene som legges for behandling og oppfølging.

\section{Konklusjon}

Med noen viktige unntak har traumatisk stressforskning kun inkludert suicidal atferd relatert til traumer i en svært begrenset grad. En grunn til dette kan være at suicidalitet i denne konteksten kan være koblet til noen av de meste problematiske aspektene ved psykiske traumer; hjelpeløshet, mangel på kontroll, følelse av verdiløshet og tap av mening. For klinikere kan det oppleves som svært ubehagelig å gå i møte med slike temaer hos pasienter, og de vil derfor kunne unngå å ta opp disse temaene og relaterte suicidale temaer med pasientene. Siden traumatisk eksponering ofte overses i kliniske sammenhenger der det ikke er det presenterte problem, forblir det også ofte uoppdaget i grupper av suicidale pasienter. Vi trenger derfor å $\varnothing$ ke klinikeres kunnskap om disse forholdene, og vi har behov for å utvikle flere behandlingsmodeller som integrerer kunnskap fra psykotraumatologi med viktig kunnskap fra suicidologi.

Referanselisten finnes $i$ artikkelen på NSSFs nettside

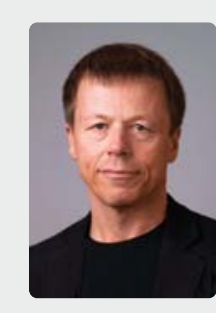

Lars Mehlum er psykiater og professor i suicidologi ved Univ. i Oslo. Han er leder for NSSF og er bredt engasjert i en rekke forsknings- og forebyggingspro sjekter. Han har publisert flere lærebøker samt en rekke vitenskapelige artikler. 


\section{Referanser}

Adams, D.M. og Lehnert, K.L. (1997). Prolonged trauma and subsequent suicidal behaviour: child abuse and combat trauma reviewed. Journal of Traumatic Stress, 10:619-34.

Adams, K.S., Buckoms, A., Streiner, D. (1982). Parental loss and family stability in attempted suicide. Archives of General Psychiatry, 39:1081 -1085 .

Allen, D.M. og Tarnowski, K.J. (1989). Depressive characteristics of physically abused children. Journal of Abnormal Child Psychology, 17:1-11.

Allen, J.G. (2001). Traumatic relationships and serious mental disorders. John Wiley \& Son, Chichester.

American Psychiatric Association (1994). Diagnostic and statistical manual of mental disorders, 4th ed.: DSM-IV. American Psychiatric Press, Washington, D.C.

Bensley, L. S., Van Eenwyk, J., Spieker, S. J., Schoder, J. (1999). Self-reported abuse history and adolescent problem behaviors. I. Antisocial and suicidal behaviors. Journal of Adolescent Health, 24:63-172.

Brady, K.T., Killeen, T.K., Brewerton, T., Lucerini, S. (2000). Comorbidity of psychiatric disorders and posttraumatic stress disorder. Journal of Clinical Psychiatry, 61 Suppl 7:22-32.

Breslau, N., Davis, G.C., Andreski, P., Peterson, E.L. (1991). Traumatic events and posttraumatic stress disorder in an urban population of young adults. Archives of General Psychiatry, 48:216 -222 .

Breslau, N., Kessler, R.C., Chilcoat, H.D., Schultz, L.R., Davis, G.C., Andreski, P. (1998). Trauma and Posttraumatic Stress Disorder in the Community: The 1996 Detroit Area Survey of Trauma. Archives of General Psychiatry, 55:626 -632.

Briere, J. og Zaidi, L.Y. (1989). Sexual abuse history and sequelae in female psychiatric emergency room patients. American Journal of Psychiatry, 146:1602-1606.

Briere, J., Woo, R., McRae, B., Foltz, J., Sitzman, R. (1997). Lifetime victimization history, demographics, and clinical status in female psychiatric emergency room patients. Journal of Nervous and Mental Disease, 185:95-101.

Bron, B., Strack, M., Rudolph G. (1991). Childhood experiences of loss and suicide attempts: Significance in depressive states of major depressed and dysthymic or adjustment disordered patients. Journal of Affective Disorders, 23:165-172.

Brown, G. R. og Anderson, B. (1991). Psychiatric morbidity in adult inpatients with childhood histories of sexual and physical abuse. American Journal of Psychiatry, 148:55-61.

Brown, J., Cohen, P., Johnson, J.G., Salzinger, S. (1998). A longitudinal analysis of risk factors for child maltreatment: Findings of a 17-year prospective study of officially recorded and selfreported child abuse and neglect. Child Abuse $\&$ Neglect, 22:1065-1078.
Brown, J., Cohen, P., Johnson, J.G., Smailes, E.M. (1999). Childhood abuse and neglect: specificity of effects on adolescent and young adult depression and suicidality. Journal of the American Academy of Child \& Adolescent Psychiatry, 38:1490-1496.

Bullman, T.A. og Kang, H.K. (1994). Posttraumatic stress disorder and the risk of traumatic deaths among Vietnam veterans. Journal of Nervous and Mental Disease, 182:604-10.

Bullman, T.A. og Kang, H.K. (1996). The risk of suicide among wounded Vietnam veterans. American Journal of Public Health, 86:662-7.

Caughlin, S., Benichou, J., Weed, D.L. (1994)

Attributable risk estimation in case-contro studies. Epidemiological Review, 16:51-63.

Cloitre, M., Scarvalone, P., Difede, J.A. (1997). Posttraumatic stress disorder, self- and interpersonal dysfunction among sexually retraumatized women. Journal of Traumatic Stress, 10:437-52.

Dahl, S. (1989). Acute response to rape - a

PTSD variant. Acta Psychiatrica Scandinavica, Suppl. 355:56-62.

Davidson, J.R.T., Hughes, D., Blazer, D.G., George, L.K. (1991). Post-traumatic stress-disorder in the community - an epidemiological study. Psychological Medicine, 21:713-21.

Davidson, J.R.T., Huges, D.C., George, L.K. Blazer, D.G. (1996). The association of sexual assault and attempted suicide within the community. Archives of General Psychiatry, 53:550-555.

Dube, S.R., Anda, R.F., Felitti, V.J., Chapman, D.P., Williamson, D.F., Giles, W.H. (2001).

Childhood abuse, household dysfunction, and the risk of attempted suicide throughout the life span: findings from the Adverse Childhood Experiences Study. Journal of the American Medical Association, 286:3089-96.

Durkheim, É. (2006). Selvmordet - en sosiologisk unders $\phi$ kelse (opprinnelig utgitt på fransk i 1897). Gyldendal, Oslo.

Fairbrother, G., Stuber, J., Galea, S., Fleischman, A.R., Pfefferbaum, B. (2003). Posttraumatic stress reactions in New York City children after the September 11, 2001, terrorist attacks. Ambulatory Pediatrics, 3:304-311.

Fontana, A. og Rosenheck, R. (1994). Traumatic war stressors and psychiatric symptoms among World War II, Korean, and Vietnam War veterans. Psychology of Aging, 9:27-33.

Fergusson, D.M., Woodward, L.J., Horwood, L.J (2000). Risk factors and life processes associated with the onset of suicidal behaviour during adolescence and early adulthood. Psychological Medicine, 30:23-39.

Ferrada-Noli, M., Asberg, M., Ormstad, K., Lundin, T., Sundbom, E. (1998a). Suicidal behavior after severe trauma. Part 1: PTSD diagnoses, psychiatric comorbidity, and assessments of suicidal behavior. Journal of Traumatic Stress, 11:103-12.
Ferrada-Noli, M., Asberg, M., Ormstad, K. (1998b) Suicidal behavior after severe trauma. Part 2: The association between methods of torture and of suicidal ideation in posttraumatic stress disorder. Journal of Traumatic Stress, 11:113-24

Floen, S.K., Elklit, A. (2007). Psychiatric diagnoses, trauma, and suicidality. Annals of General Psychiatry 6:12.

Glad, K.A., Aadnanes, M., Dyb, G. Opplevelser og reaksjoner hos de som var på Ut $\varnothing$ ya 22.juli 2011. En deloppsummering fra prosjektgruppen. Nasjonalt Kunnskapssenter om Vold og Traumatisk Stress, Oslo, 2012.

Goldney, R.D., Wilson, D., Dal Grande, E., Fisher, L.J., McFarlane, A.C. (2000). Suicidal ideation in a random community sample: attributable risk due to depression and psychosocial and traumatic events. Australia and New Zealand Journal of Psychiatry, 34:98-106.

Gould, D.A., Stevens, N.G., Ward, N.G., Carlin, A.S., Sowell, H.E., Gustafson, B. (1994). Selfreported childhood abuse in an adult population in a primary care setting. Prevalence, correlates, and associated suicide attempts. Archives of Family Medicine, 3:252-256.

Gradus, J.L., Qin, P., Lincoln, A.K., Miller, M., Lawler, E., Sørensen, H.T., Lash, T.L. (2010).

Posttraumatic stress disorder and completed suicide. Am J Epidemiol. 15;171(6):721-7.

Grubisic-Ilic, M., Kozaric-Kovacic, D., Grubisic, F., Kovacic, Z. (2002). Epidemiological study of suicide in the Republic of Croatia - comparison of war and post-war periods and areas directly and indirectly affected by war. European Psychiatry, 17:259-64.

Hawton, K., Rodham, K., Evans, E., Weatherall, R. (2002). Deliberate self harm in adolescents: self report survey in schools in England. British Medical Journal, 23:1207-11.

Heikkinen, M., Aro, H., Lonnqvist, J. (1994). Recent life events, social support and suicide. Acta Psychiatr Scand Suppl., 377:65-72.

Kaplan, M.L., Asnis, G.M., Lipschitz, D.S., Chorney, P. (1995). Suicidal behavior and abuse in psychiatric outpatients. Comprehensive Psychiatry, 36:229-235.

Kaplan, A.M., Efroni E., Kotler. (1999). Suicide risk and coping styles in posttraumatic stress disorder patients. Psychotherapy and psychosomatics, $68: 76-81$

Kapur, N., While, D., Blatchley, N., Bray, I., Harrison, K. (2009). Suicide after leaving the UK armed forces - a cohort study. PLoS Med 6:e26.

Kendall-Tackett, L. The health effects of childhood abuse: four pathways by which abuse can influence health. (2002). Child Abuse \& Neglect, 26:715-729.

Kessler, R.C., Sonnega, A., Bromet, E., Hughes, M., Nelson, C.B. (1995). Posttraumatic Stress disorder in the National Comorbidity survey. Archives of General Psychiatry, 52:1048-1060. 
Kramer, T.L., Lindy, J.D., Green, B.L., Grace. M.C., Leonard, A.C. (1994). The comorbidity of post-traumatic stress disorder and suicidality in Vietnam veterans. Suicide \& Life Threatening Behavior, 24:58-67.

Lipschitz, D.S., Winegar, R.K., Nicolaou, A.L., Hartnick, E., Wolfson, M., Southwick, S.M. (1999). Perceived abuse and neglect as risk factors for suicidal behaviour in adolescent inpatients. Journal of Nervous and Mental Disease, 187:32-9.

Litz, B.T., Orsillo, S.M., Friedman, M., Ehlich, P., Batres, A. (1997). Posttraumatic stress disorder associated with peacekeeping duty in Somalia for U.S. military personnel. American Journal of Psychiatry, 154:178-84.

Marshall, R.D., Olfson, M., Hellman, F., Blanco, C., Guardino, M., Struening, E.L. (2001). Comorbidity, impairment, and suicidality in subthreshold PTSD. Am J Psychiatry 158(9): 1467-73.

Mazza, J.J. og Reynolds, W.M. (1999). Exposure to violence in young inner-city adolescents: relationships with suicidal ideation, depression, and PTSD symptomatology. Journal of Abnormal Child Psychology, 27:203-13.

Mehlum, L. og Weisæth, L. (2002). Predictors of post-traumatic reactions in Norwegian UN peace-keepers seven years after service. Journal of Traumatic Stress, 15:17-26.

Mehlum L. (2012). Dialectical behaviour therapy for suicidal and self-harming adolescents. 14th European Symposium on Suicide Research and Prevention, Tel Aviv 3.-7.09.2012.

Molnar, B.E., Buka, S.L., Kessler, R.C. (2001). Child sexual abuse and subsequent psychopathology: results from the National Comorbidity Survey. American Journal of Public Health, 91:753-760.

Ness, D.E. og Pfeffer, C.R. (1990). Sequelae of bereavement resulting from suicide. American Journal of Psychiatry, 147:279-285.

Oquendo, M.A., Friend, J.M., Halberstam, B., Brodsky, B.S., Burke, A.K., Grunebaum, M.F., Malone, K.M., Mann, J.J. (2003). Association of comorbid posttraumatic stress disorder and major depression with greater risk for suicidal behavior. American Journal of Psychiatry, 160:580-2.

Orbach, I. (1994). Dissociation, physical pain, and suicide: a hypothesis. Suicide \& Life Threatening Behavior, 24:68-79.

Prigerson, H.G., Bridge, J., Maciejewski, P.K., Beery, L.C., Rosenheck ,R.A., Jacobs, S.C., Bierhals, A.J., Kupfer, D.J., Brent, D.A. (1999). Influence of traumatic grief on suicidal ideation among young adults. American Journal of Psychiatry, 156:1994-5.

Qin, P. og Mortensen, P.B. (2003). The impact of parental status on the risk of completed suicide. Archives of General Psychiatry, 60:797-802.
Raes, F., Hermans, D., de Decker, A., Eelen, P. Williams, J.M.G. (2003). Autobiographical memory specificity and affect regulation: an experimental approach. Emotion, 3:201-206.

Santa Mina, E.E. og Gallop, R.M. (1998). Childhood physical and sexual abuse and adult selfharm and suicidal behaviour: A literature review. Canadian Journal of Psychiatry, 43:793-800.

Schlenger, W.E., Caddell, J.M., Ebert, L., Jordan, B.K., Rourke, K.M., Wilson, D., Thalji, L., Dennis, J.M., Fairbank, J.A., Kulka, R.A. (2002). Journal of the American Medical Association, 288:581-8.

Schuster, M.A., Bradley, D., Stein, B.D., Jaycox, L., Collins, R.L., Marshall, G.N., Elliott, M.N., Zhou, A.J., Kanouse, D.E., Morrison, J.L., Berry, S.H. (2001). A national survey of stress reactions after the September 11, 2001, terrorist attack. New England Journal of Medicine, 345:1507-1512. Silverman, A. B., Reinherz, H. Z., Giaconia, R. M. (1996). The long-term sequelae of child and adolescent abuse: A longitudinal community study. Child Abuse \& Neglect, 20:709-723.

Stanley, B., Gameroff, M.J., Michalsen, V., Mann, J.J. (2001). Are suicide attempters who selfmutilate a unique population? American Journal of Psychiatry, 158:427-432.

Startup, M., Heard, H., Swales, M., Jones, B., Williams, J.M.G., Jones, R.S. (2001). Autobiographical memory and parasuicide in borderline personality disorder. British Journal of Clinical Psychology, 40:113-20.

Sætre, M., Holter, H., \& Jebsen, E. (1986). Tvang til seksualitet. En unders $\phi$ kelse av seksuelle overgrep mot barn. Oslo, Cappelen.

Tanielian T., Jaycox, L.H. (red). (2008). Invisible wounds of war. Psychological and cognitive in juries, their consequences, and services to assist recovery. RAND Corporation, Santa Monica.

Thoresen, S., Mehlum, L., Moller, B. (2003). Suicide in peacekeepers. A cohort study of mortality from suicide in 22,275 Norwegian veterans from international peacekeeping operations. Social Psychiatry and Psychiatric Epidemiology, 38:605-610.

Ullman, S.E. og Brecklin, L.R. (2002). Sexual assault history and suicidal behavior in a national sample of women. Suicide \& Life Threatening Behavior, 32:117-30.

Van der Kolk, B.,A., Perry, J.C., Herman, J.L. (1991). Childhood origins of self-destructive behavior. American Journal of Psychiatry, 148:1665-1671.

Wasserman, D. og Cullberg, J. (1989). Early separation and suicidal behaviour in the parental homes of 40 consecutive suicide attempters. Acta Psychiatrica Scandinavica, 79:296-302.

White, H.R. og Widom, C.S. (2003). Does childhood victimization increase the risk of early death? A 25-year prospective study. Child Abuse $\&$ Neglect, 27:841-853.
Widom, C.S. (1999). Posttraumatic stress disorder in abused and neglected children grown up. American Journal of Psychiatry, 156:8: 1223-1229

Wilcox, H.C., Storr, C.L., Breslau, N. (2009). Posttraumatic Stress Disorder and Suicide Attempts in a Community Sample of Urban American Young Adults. Archives of General Psychiatry, 66:305-311.

Williams, J.M., Ellis, N.C., Tyers, C., Healy, H., Rose, G., MacLeod, A.K. (1996). The specificity of autobiographical memory and imageability of the future. Memory \& Cognition, 24:116-25.

Yehuda, R. Post-Traumatic Stress Disorder. (2002). New England Journal of Medicine, 348:108-114.

Ystgaard, M., Hestetun, I., Loeb, M., Mehlum, L. (2004). Is there a specific relationship between childhood sexual and physical abuse and repeated suicidal behavior? Child Abuse and Neglect, $2(8): 863-75$.

Zimmerman, M. og Mattia, J.I. (1999). Is posttraumatic stress disorder underdiagnosed in routine clinical settings? Journal of Nervous and Mental Disease, 187:7:420-428. 